\title{
Dampak Yang Ditimbulkan Pandemi Covid-19 terhadap Proses Pembelajaran
}

\author{
Maili Yusma \\ E-mail: maili.yusma0726@student.unri.ac.id
}

Program Studi Pendidikan Bahasa dan Sastra, Universitas Riau

\section{Pengantar}

Pandemi Covid-19 atau yang biasa disebut masyarakat virus korona telah mengubah tatanan kehiduman dalam masyarakat. Hal itu menuntut kehidupan berubah menjadi begitu cepat. Berbagai sektor kehidupan dalam masyarakat terganggu fungsinya akibat virus berbahaya yang tengah melanda saat ini. Kesehatan menjadi poin paling utama yang terpengaruh akibat adanya virus yang melanda. Namun demikian, pendidikan adalah salah satu sektor yang ikut terganggu fungsinya akibat keberadaan pandemi yang tengah melanda. Pembatasan wilayah hingga aturan menjaga jarak membuat semua orang harus menghentikan kegiatan di luar rumah. Hal inilah yang membuat semua kegiatan pembelajaran tatap muka di sekolah ataupun Universitas dihentikan dan digantikan dengan Pembelajaran Jarak Jauh (PJJ) dengan metode dalam jaringan (Daring).

Kebijakan peralihan pembelajaran menggunakan media online inilah yang mengalami banyak sekali kendala. Terlebih lagi, ini hal yang baru bagi sebagian kalangan melakukan pembelajaran Jarak Jauh melalui jaringan internet. Bagi siswa ataupun mahasiswa yang berada di pelosok dan susah sekali mendapatkan jaringan internet, hal ini sangat mengganggu konsentrasi belajar agar tetap fokus. Hal inilah yang kemudian menimbulkan permasalahan dari segi pembelajaran maupun segi psikologi peserta didik. 


\section{Pandemi Covid-19}

Virus Covid-19 saat ini telah ditetapkan oleh World Healt Organization (WHO) sebagai pandemi sejak tanggal 11 Maret 2020. Penetapan pandemi Virus Covid-19 adalah yang pertama kalinya sejak tahun 2009. Jika dilihat dari statistik penyebaran Covid-19, hal ini sangat menghawatirkan dimana menurut data persebaran yang dikutip oleh https://covid19.go.id/ terlihat telah menjangkit 34 provinsi di Indonesia.

Gejala umum yang dialami oleh orang yang terinfeksi yaitu demam, sesak nafas dan batuk. Gejala lain yang dapat dialami oleh pasien yang terinfeksi yaitu sakit tenggorokan, nyeri otot, adanya dahak, gangguan pencernaan seperti diare, sakit perut, dan kehilangan fungsi indra pengecap dan pencium. Sementara sebagian besar kasus pasien mengalami gejala ringan namun pada gejala yang lebih serius berkembang menjadi kegagalan fungsi beberapa organ dan pneumia.

Sebagai upaya untuk mencegah penularan virus ini, mentri pendidikan dan kebudayaan mengeluarkan surat edaran N0 3 tahun 2020. Surat Edaran Sekjen Kemendikbud No 36603/A.A5/OT/2020 pada 15 Maret 2020. Adapun poin-poin penting yang tertera dalam surat edaran yaitu:

1. Menunda penyelenggaraan sebuah acara yang bersifat mengundang peserta yang banyak atau bisa mengganti dengan video conference.

2. Pejabat pimpinan tinggi madya, Pimpinan Tinggi Pratama, dan pimpinan unit lainnya untuk bertanggung jawab atas pencegahan sekaligus penanganan Covid-19.

3. Pimpinan dan pegawai diwajibkan untuk bekerja di rumah tanpa 
mengurangi kinerja, tanpa mengurangi kehadiran, dan tanpa mengurangi tunjangan.

4. Pimpinan atau pegawai yang sedang tidak enak badan atau sakit diwajibkan beristirahan di rumah.

5. Pegawai Kemendikbud yang menggunakan transportasi publik akan disediakan alat transportasi untuk sarana datang ke kantor.

6. Pengola sistem persuratan adaan dokumentasi elektronik harus menjaga sistem dengan baik agar dapat digunakan untuk bekerja dari jarak jauh.

7. Kepala Pusat Data dan Informasi (Pusdatin) untuk berkoordinasi dengan biro umum dan Pengadaan Barang dan Jasa, untuk menyiapkan sarana dan prasarana serta tanda tangan elektronik melalui SINDE, digital dokument, video conference, dan lain-lain.

Semenjak kebijakan ini diberlakukan, menanggapi surat edaran tersebut hampir seluruh instansi pemerintahan terutama sekolah-sekolah memutuskan untuk melakukan pembelajaran di rumah. Tidak dilakukannya pembelajaran tatap muka di sekolah bukan berarti proses pembelajaran benar-benar diberhentikan, namun digantikan dengan proses Pembelajaran Jarak Jauh dengan menggunakan media Online (Dalam Jaringan). Atas apa yang telah melanda, tidak dapat dipungkiri bahwa musibah pandemi Covid-19 telah mengguncang dunia pendidikan di Indonesia.

Semua jenjang pendidikan, mulai dari PAUD, SD, SMP, SMA / kejuruan, termasuk perguruan tinggi mengambil kebijakan untuk belajar dari rumah. Dengan mewabahnya virus korona ini pula yang menyebabkan diberlakukannya kebijakan Work From Home. Hingga akhirnya sekolah dan kampus secara nasional melakukan pembelajaran daring. Kenyataan ini yang menjadikan Pandemi Covid-19 berdampak serius terhadap sektor 
pendidikan secara global (Khasanah, Lestari, Rahman, \& Daniel, 2020)

Pengalihan Proses Pembelajaran Akibat Pandemi dan Dampak Terhadap Proses Pembelajaran

Tidak dapat dipungkiri bahwa saat wabah Pandemi Covid-19 melanda, satu-satunya alternatif yang dapat dilakukan sebagai pengganti pembelajaran tatap muka hanyalah belajar menggunakan media Online atau yang biasa disebut belajar dalam jaringan.

Menurut Syarifudin (2020), pembelajaran daring dapat dijadikan solusi pembelajaran jarak jauh ketika terjadi bencana. Seperti yang terjadi ketika pemerintah menetapkan kebijakan sosial distancing. Sosial distancing diterapkan oleh pemerintah dalam rangka membatasi interaksi manusia dan menghindarkan masyarakat dari kerumunan agar terhindar dari penyebaran virus. Hal inilah yang menjadikan proses pembelajaran dilakukan dari rumah. Pemerintah mengganti pembelajaran denga sistem pembelajaran daring melalui aplikasi pembelajaran daring yang sudah ada. Dengan adanya kebijakan ini menjadikan pembelajaran daring menjadi satu-satunya pilihan untuk pembelajaran.

Selain ucapan syukur atas adanya alternatif yang dapat digunakan untuk menggantikan pembelajaran tatap muka, tentu saja pembelajaran jarak jauh dalam jaringan ini juga tidak terlepas dari kelemahan tertentu yang berdampak pada proses pembelajaran. Usaha untuk menyelamatkan peserta didik dari virus yang berbahaya ternyata telah menimbulkan beberapa dampak khususnya pada peserta didik, guru, dan orang tua. Peserta didik sendiri akan merasa terpaksa belajar dari rumah yang sebenarnya tidak memiliki fasilitas yang memadai untuk hal tersebut, dengan begitu maka proses pembelajaran akan terhambat yang seharusnya sebelum dimulainya pembelajaran tersebut fasilitas pendukung harus tersedia lebih dahulu. Kemudian selanjutnya terletak pada proses adaptasi pembelajaran, peserta didik yang tadinya cenderung 
berinteraksi langsung dalam pembelajaran akan memerlukan berbagai macam adaptasi belajar serta memahami pembelajaran yang di modelkan dalam jaringan, sehingga kebijakan yang diberikan bisa saja menimbulkan mandeknya pemahaman peserta didik terhadap pembelajaran.

Hal yang menjadi pokok permasalahan bagi peserta didik adalah perubahan lingkungan belajar offline menjadi online. Dengan berubahnya lingkungan belajar tersebut maka membutuhkan hal yang akan menarik minat peserta didik untuk belajar sehingga peserta didik akan merasa antusias dengan proses pembelajaran yang dilakukan.

Selain hal itu, jaringan internet yang digunakan untuk melakukan pembelajaran daring juga perpengaruh penting terhadap lancarnya proses pembelajaran. Sehingga peserta didik yang berada di wilayah terpencil yang tidak terjangkau jaringan internet akan sangat terganggu proses pembelajarannya.

Dampak selanjutnya tentu terletak pada tenaga pengajar atau guru.sebagai seorang pendidik tentunya memiliki tanggung jawab terhadap proses pembelajaran peserta didiknya, namun akibat dari pandemic covid-19 dan berlakunya kebijakan WFH maka proses pembelajaran ikut terdampak dikarenakan beberapa hal yang menjadi hambatan bagi guru untuk melakukan proses pembelajaran secara online.

\section{a. Keterbatasan Pengetahuan Tekhnologi}

Keterbatasan penggunaan tekhnologi menjadi hambatan yang signifikan bagi proses pembelajaran yang dilakukan oleh guru, hal tersebut dikarenakan masih banyaknya guru-guru senior atau yang sudah berumur namun tidak melek terhadap penggunaan tekhnologi pembelajaran berbasis online tersebut. Sehingga seharusnya terlebih dahulu diperlukan proses pelatihan untuk para guru-guru dalam peningkatan kapasitas mengajar berbasis media online tersebut. 


\section{b. Keterbatasan Sarana dan Prasarana}

Fasilitas sebagai penunjang dalam proses pembelajaran tidak boleh terhambat. Keterbatasan sarana dan prasarana tentunya akan berdampak pula terhadap proses transfer pengetahuan. Dampak dari kebijakan bekerja dari rumah membuat banyaknya tenaga pendidik yang sedari awal bertatap muka langsung menyebabkan ketersediaan perangkat online tidak memadai. Sehingga seharusnya persiapan perangkat seperti laptop, jaringan, handphone harus dipersiapkan agar proses pemberian materi menjadi lebih baik.

\section{c. Keterbatasan Pengalaman Pembelajaran Online}

Proses pembalajaran yang selama ini dilakukan sebelum pandemi tentunya membuat guru sangat minim dalam pembelajaran secara online. Hal tersebut akan berdampak pada proses penyampaian materi juga penyampaian pemahaman kepada peserta didik, yang berakibat pada tidak efektifnya pembelajaran. Guru yang dari awal melakukan proses tatap muka justru kemudian di paksa untuk memberikan pelajaran melalui perangkat internet. Sehingga bisa saja berdampak pada kejenuhan ataupun kebosanan guru sehingga malas untuk memberikan pembelajaran kepada peserta didiknya.

\section{Penutup}

Kita semua telah mengetahui bahwa Pandemi Covid-19 telah memaksa seluruh sektor bertransformasi secara tiba-tiba dan segala kegiatan-kegiatan berbasis offline berubah menjadi online. Lahirnya kebijakan MENDIKBUD untuk bekerja dari rumah dan belajar dari rumah menjadi salah satu upaya menjaga masyarakat dari pandemi covid-19 yang tengah mewabah. Namun, di satu sisi kebijakan tersebut telah berdampak banyak pada proses pendidikan baik bagi siswa, maupun guru dan juga keluarga atau orang tua. Hal yang menjadi permasalahan utama yaitu ketidaksiapan fasilitas dan kurangnya pengalaman dan bahkan ada 
yang sama sekali belum pernah berada dalam kondisi tersebut yang membuat proses belajar membutuhkan waktu untuk beradaptasi terlebih dahulu dengan sistem belajar daring. Hal inilah yang membuat keterlambatan proses pebelajaran teritama bagi siswa-siswi yang berada di desa dengan kondisi wilayah yang sulit sekali jaringan internet. Oleh karenanya, perlu kiranya dilakukan pembaruan model pendidikan yang sesuai dengan kondisi pandemic namun tidak menimbulkan dampak pada proses pembelajaran, misalnya melakukan pembelajaran kontekstual yang berbasis kehidupan sehari-hari peserta didik.

\section{Referensi}

Hasanah, A., Lestari, A. S., Rahman, A. Y. , \& Daniel, Y. I. (2020). Analisis Aktivitas Belajar Daring Mahasiswa pada Pandemi Covid-19. http://digilib.uinsgd.ac.id/30565

Syarifudin, A. S. (2020). Implementasi Pembelajaran Daring Untuk Meningkatkan Mutu Pendidikan Sebagai Dampak Diterapkannya Social Distancing. Jurnal Pendidikan Bahasa dan Sastra Indonesia Metalingua, 5(1), 31-34.

\section{Pembelajaran masa Covid-19 1}

http://139.59.120.216/index.php/jurnalkependidikan/article/download/28 $65 / 2143$

Zulhafizh. (2020). Membina Aktivitas Belajar Mahasiswa di Perguruan Tinggi Melalui Metode TIE (Translation, Interpretation, Extrapolation) pada Masa Pandemi Covid-19. Jurnal Kependidikan: Jurnal Hasil Penelitian dan Kajian Kepustakaan di Bidang Pendidikan, Pengajaran dan Pembelajaran, 6(3), 502-511.

Pembelajaran masa Covid-19 2

https://pajar.ejournal.unri.ac.id/index.php/PJR/article/view/8080/pdf Zulhafizh \& Permatasari, S. (2020). Developing Quality of Learning in the Pandemic Covid-19 Through Creative and Critical Thinking Attitudes. JURNAL PAJAR (Pendidikan dan Pengajaran), 4(5), 937-949. 


\section{Data Penulis}

Maili Yusma, lahir di desa Teberau Panjang, kecamatan Gunung Toar, kabupaten Kuantan Singingi, Riau. la alumni dari SMA N 1 Teluk Kuantan dan saat ini tengah menjalani kuliah semester 5 di Program Studi Pendidikan Bahasa dan Sastra Indonesia, Fakultas Keguruan dan IImu Pendidikan (FKIP) di Universitas Riau (UR). la berhasil masuk Universitas Riau melalui jalur Seleksi Nasional Masuk Perguruan Tinggi Negri (SNMPTN). Prestasi yang pernah diraihnya selama kuliah di Universitas Riau yaitu menang juara pertama lomba tulis puisi tingkat nasional dalam agenda Praktikum Sastra yang rutin diadakan sekali setahun di Program Studi Pendidikan Bahasa dan Sastra Indonesia, Universitas Riau.

Kontak

WA $\quad: 0822-8568-6655$

E-mail : maili.yusma0726@student.unri.ac.id 